The Philosophical Journal of Conflict and Violence

Vol. II, Issue $1 / 2018$

(C) The Authors 2018

Available online at http://trivent-publishing.eu/

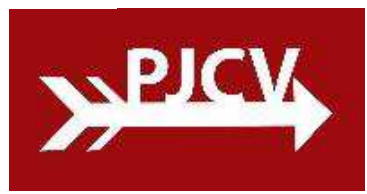

\title{
Dirty Pleasures: \\ The Ethics of the Representation of Sexual Violence
}

\author{
David Edward Rose
}

Newcastle University, United Kingdom

\begin{abstract}
The aim of this paper is to assert that any moral critique or political censorship of sexually violent imagery cannot be justified with reference to participants nor matters of taste. Rather, the present paper seeks to distinguish objectification and alienation and apply this distinction to the issue of the representation of sexual violence. Alienation is the morally problematic category because systems of domination and control determine the expressions and consumption of desires, but this means that the violence in such material may well be a red herring.
\end{abstract}

Keywords: Alienation; Capitalism; Censorship; Cultural fabric; Objectification; Pornography; Sexually violent material.

DOI: 10.22618/TP.PJCV.20182.1.171006

\section{TRIVENT}

The PJCV Journal is published by Trivent Publishing

This is an Open Access article distributed in accordance with the Creative Commons Attribution Non Commercial (CC-BY-NC-ND 4.0) license, which permits others to copy or share the article, provided original work is properly cited and that this is not done for commercial purposes. Users may not remix, transform, or build upon the material and may not distribute the modified material (bttp:/ / creativecommons.org/ licenses/ by-nc/4.0/) 


\title{
Dirty Pleasures: The Ethics of the Representation of Sexual Violence
}

\author{
David Edward Rose \\ Newcastle University, United Kingdom
}

\begin{abstract}
The aim of this paper is to assert that any moral critique or political censorship of sexually violent imagery cannot be justified with reference to participants nor matters of taste. Rather, the present paper seeks to distinguish objectification and alienation and apply this distinction to the issue of the representation of sexual violence. Alienation is the morally problematic category because systems of domination and control determine the expressions and consumption of desires, but this means that the violence in such material may well be a red herring.
\end{abstract}

Keywords: Alienation; Capitalism; Censorship; Cultural fabric; Objectification; Pornography; Sexually violent material.

\section{The Problem is not Consensual Participation}

$\$ 1$. One problem of the liberal defences of the existence, exchange and consumption of pornography is that these liberals are defending a pornography which is, by contemporary standards, innocent. It is easy to defend the actress who participates in a standard sex film as being able to decide for herself and to accuse the critic of pornography ${ }^{1}$ of relying on a puritanical social context to argue she would much prefer to be a teacher or lawyer, if only she knew her real interests, but not so easy when "The user is bombarded with images of mascara running, hair being pulled, throats in a vicelike grip, nostrils being pinched so women can't breathe as the penis fills the mouth, and mouths that are distended by either hands pulling the lips apart or penises inserted sideways." 2 When Ronald Dworkin, for example, defended the free speech of pornographers, he was concerned with a minority issue and perhaps quaint stag films which no more resemble the actual pornography of today than Milton's Paradise Lost is to be judged by the understandings of contemporary novels. ${ }^{3}$ Such violent images of humiliation are, however, also present in mainstream

\footnotetext{
${ }^{1}$ In this article the "critic of pornography" remains somewhat anonymous just because it is a rhetorical amalgamation of several views.

${ }^{2}$ Gail Dines, Pornland: How Porn Has Hijacked Our Sexuality (Boston: Beacon Press, 2014), xix-xx.

3 Ronald Dworkin, "Is There A Right to Pornography?” Oxford Journal of Legal Studies 1.2 (1981): 177_ 212. For a deeper discussion of Dworkin and his liberalism, see David Rose, The Ethics and Politics of Pornography (Basingstoke: Palgrave Macmillan, 2013): 87-7, 107-12, 164-67.
} 
imagery: Spiderwoman's binding by Hangman, the bound and flagellated Ornella Muti in Flash Gordon, and the suspended naked woman in Hostel: Part II. ${ }^{4}$

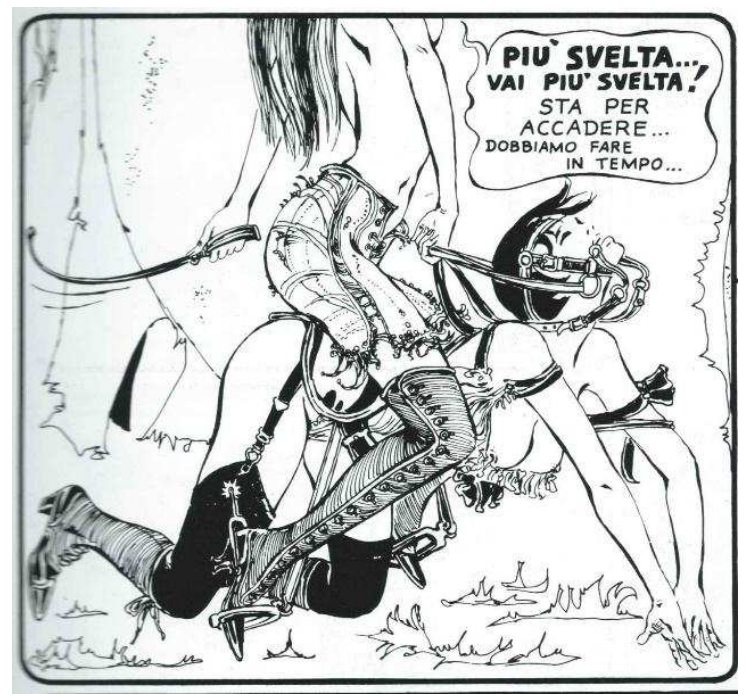

Fig. 1: Guido Crepax, Valentina vol. 5 (Roma: Blue Press, 1995): 9.

\$2. The problem of humiliation and pain in pornographic and non-pornographic representations is not one of consent. If it were, the above image or the words of the Marquis de Sade (where there are no participants and no victims) would be morally uninteresting. They are not. The use of minors in the production of pornography is explicitly forbidden, but the simulation of minors through animation in hentai, the techniques to make actors appear younger, as well as literary descriptions of sexual relationships with minors is also (putatively) morally and legally forbidden. Consent is not the be all and end all in those cases either.

\$3. Even if one were to ignore the interest in violent images without participants and concentrate on pornographic films or photographic images of humiliation and pain where actors or models are represented in pain or being harmed, then consent would still not be an issue. It is empirically true that certain individuals enjoy sexual practices involving humiliation, pain and bondage. A liberal state cannot dictate which activities are permissible once consent is given by the participants (one can beat another in the boxing ring or the dojo) and in a free market, representations of such activities can be organised, recorded and exchanged for money. Like boxing, limits can be put on when, how and identify the appropriate health and safety regulations as well as restricting who can consume and when (to mitigate problems of damage to immature minds and public decency), but such activities cannot be prohibited without finding evidence of coercion or reckless harm.

\footnotetext{
${ }^{4}$ Marv Wolfman "Hell is the Hangman!”. Spiderwoman. 1.4. (New York: Marvel Publications, 1978); Mike Hodges, dir. Flash Gordon (Starling Films, 1980): 111 mins; Roth, Eli, dir. Hostel: Part 2 (Lionsgate, 2007): 94 mins.
} 
$\$ 4$. However, some may claim that no participant in recorded material involving sexual violence would do so willingly. ${ }^{5}$ In the interest of art, pain and privation are intelligible within rational limits (actors often suffer for specific roles), but participants in sexually violent material would obviously prefer to earn their money as a teacher or a lawyer, it is just that economic necessity coerces them to "consent" to the activity.

\$5. Such an assertion is unfair and problematic since it assumes that one is unable to make such decisions properly on one's own. Many individuals do jobs which they would prefer not to or would prefer to do something else. Exploitation occurs when the individuals are forced to participate in activities with excessive risks of harm or due to unfair pressure by employers, but in such cases robust employment law is in place to protect these individuals. Exploitation occurs in all industries and would be as wrong in circus performers and cockle pickers as in pornographic actors. The nature of the activity is incidental to the wrongdoing. The rights of the actresses are covered by Health and Safety and Employment Law and is no different to the job performance of a stunt artist. One assumes that the actresses in $W$ asteland also have their rights protected (given the professional nature of the production) and the harm they suffer is consensual. ${ }^{6}$ Consent sets a limit to the degree of privation an actor is prepared to suffer for his or her art.

\$6. Yet, as in dangerous work, the actual fact of making such material is often taken as evidence that the actors do not do so freely. Just like the actor who plays the role of the victim in a snuff movie, there is no rational way they would agree willingly to participate. There is however a difference between a snuff movie and sexually violent material. When one encounters the agent apparently intending to willingly act in a snuff film, just as when one is confronted by an agent intending to commit suicide, it is eminently sensible and quite right to mistrust his or her avowed intention. At the very least, one would demand to know more about his or her motivations rather than the immediate surface desire and ensure that any decision is freely and rationally taken (which begins from the very high bar of being nigh on impossible). Given $\ 2$, though, if sane adults tell one that they enjoy sadistic and masochistic practices, it is plausible. And if a particular actor enjoyed her work in sexually violent films, was good at it and found satisfaction in it, more so than in teaching, being a lawyer or working in a factory, then one could only contradict her at the cost of her own rationality, to treat her as not autonomous and to decide for her the types of lives and values which are worthwhile. In the snuff movie, we probably know better what the actor wants (not his death), but it is not so obvious that, in the cases of the boxer and the BDSM actor, one is not guilty of assuming one knows better than others. As good liberals know, outside non-controversial issues of public health and obvious cases of impaired rationality, any claim that a subject is suffering from bad faith, false consciousness or ideological distortion is hard to establish given the long series of historical efforts by moralists choosing for the sake of others. To do so, is to assume that such participants are not fully rational and that is to undermine the autonomy of individuals for the sake of a commitment to a value of the worthlessness of an activity that others may not share. No matter how much

\footnotetext{
${ }^{5}$ Catherine Mackinnon, Only Words (Cambridge, USA: Harvard University Press, 1993).

${ }^{6}$ Graham Travis, dir. Wasteland (Elegant Angel, 2012): 134 mins. Travis's film is an example of the mainstream-adult industry boundary whereby a pornographic film goes beyond the gratuitous use of images for arousal to attempt to express meaning. The end scene is a crescendo of sexual violence between two competing-recognising female self-consciousnesses. The males (many masked) remain largely identity-less and nothing but the distribution of a negated objectification. It is not wholly, I should stress, an aesthetic success.
} 
we object, the right to free speech protects the individual from interference by more powerful agents (the state, religions and so on). We must tolerate those who have tastes different from our own and pursue ways of life which do not share some of our values.

\section{A Matter of Taste}

\$ 7 . The claim about really not wanting to participate in such films hides a negative opinion on such activities. If one wants to spend one's time jogging, crocheting or skiing, that is one's own business. If one wants to spend one's free time killing random passers-by then that is the business of the state because it involves non-consensual harm to others, unlike boxing which involves consensual harm. If one wants to enjoy participating-or watching sexually violent imagery, and such imagery has been produced with the consent of the participants, then it is no different to participating — or watching - a boxing match. Any argument against its production and consumption is then based on value judgements: the activity is not worthwhile, is not what you should be doing. And one cannot help feeling the same sort of puritanism here about pornography in general: one should not watch this, it is trivial, of no value. One should not watch these films or enjoy these films, as it is evidence of baseness.

\$ 8. Human beings enjoy many trivial and valueless activities. Defenders of these images may say that they are art, that they are media for the expressions of deeper truths of human existence. One ought to here be more forthright and less disingenuous. There are good and bad pornographic films just as in all other genres and one does not want to limit oneself to defending only those of artistic value, howsoever such a value is to be established. One should not be afraid to say one watches pornography to be aroused. One watches horror films to be scared, to feel emotions of fear, and one watches pornographic films to be aroused, to feel feelings of arousal. And one watches, reads and consumes sexually violent images, bondage and BDSM in order to be aroused.

\$9. The representation of sexual violence involves cruelty, harm and humiliation. Consumers enjoy and take pleasure from seeing others harmed, humiliated and abused. The judgment which requires thought is that: one should not enjoy consuming images of sexual violence, humiliation and cruelty. When watching such material, if a third person were to spy you, they would exclaim: "How can you be aroused by that? There is something wrong with you..." And because it is normative, it grounds legal and moral claims for the prohibition, censorship of violent pornography. The judgement one makes is: "You ought not to consume images or representations of sexual violence" or "One should not enjoy consuming images of sexual violence, humiliation and cruelty." But do we mean that there

\footnotetext{
${ }^{7}$ Here I want to sidestep the paradox of horror, the puzzle about why people want to watch images that elicit negative attitude or emotions. See Noel Carroll, The Pbilosophy of Horror, Or, Paradoxes of the Heart (New York: Routledge, 1990); Noel Carroll, "Enjoying Horror Fictions: A Reply To Gaut," The British Journal of Aesthetics 35.1 (1995): 67-72; Berys Gaut, "The Paradox Of Horror," The British Journal of Aesthetics 33.4 (1993): 333-45; Berys Gaut, "The Enjoyment Theory Of Horror: A Response To Carroll," The British Journal of Aesthetics 35.3 (1995): 284-89; Matthew Strohl, "Horror and Hedonic Ambivalence," The Journal of Aesthetics and Art Criticism 70.2 (2012): 203-12. With sexually violent images, viewers are aroused by images that are disquieting, that, if real, would disturb. Here there is a difference from the paradox of horror in that though there is something to explain, there is more pertinently something to justify or excuse oneself for. With horror we have an explanatory problem, with violent pornography we have a normative problem. The former is a problem of psychology and not philosophy.
} 
is something wrong with me if I "enjoy" or am aroused by it, or do we mean that I should not do it, even if I enjoy it (like smoking or squishing ants)?

$\$ 10$. The claim that you ought not to consume it (if true) gives legislators the justification to ban it. To prefer Black Sabbath to Beethoven is a case of bad taste. However, it is one's own prerogative to prefer to listen to Sabbath rather than Ludwig. In the British philosophical tradition, desires and preferences are non-rational, they are natural facts. ${ }^{8}$ Yet, even in matters of taste we often state that one may well like $\mathrm{X}$ but ought to, all things considered, prefer Y. Beliefs, experiences and idiosyncrasies determine the individual's relation to a given object. When one prefers KFC to a Michelin starred restaurant, or Black Sabbath to Beethoven, one is guilty of bad taste (allegedly). The best that "bad taste" can signify is that one's pleasures are abnormal, unusual and not shared.

$\$ 11$. One who likes the flavour of faeces, though, is a pervert because, all things considered, one ought not to like the flavour of shit (for natural reasons). One who is aroused by images of sexual violence is perhaps a pervert. ${ }^{9}$ One possible explanation of such perversions and "ought" judgements of taste is the prudential one: we have many desires and they conflict. One desires to smoke but one desires a long and happy life. We can make mistakes about which desire should have priority or will be stronger. So to like the taste of faeces is a perversion because our natural organism has evolved to identify harmful substances with unpleasant flavours. In normal circumstances, those desires which are best suited to the furtherance of the organism will have priority. So, for example, you should not smoke because it does not benefit, but harms us. Your pleasure for the instant ought to be sacrificed for the pleasure of health.

\$12. But this does not work. There are no competing desires about health and sexual violence, nor economic ones (imagine arguing someone should not buy a Rolls Royce because it harms their long-term interests, or one should not play computer games because it damages one's memory). There is no long-term damage which seems to result from the consumption of violent imagery. ${ }^{10}$ There might be from the participation in it, but no more than the risks when one snowboards or rock climbs. And these sports are televised for the entertainment of the masses. Any moral degradation will be no more that playing Grand Theft Auto on a console. (See $\int 27$.)

$\$ 13$. To talk about perversion, one might need to turn to a slightly different tradition of philosophy and the purification of desires. ${ }^{11}$ Imagine finding a dying cat on the road who is beyond medical help. The animal is obviously suffering, and this could be alleviated by ending its life there. You want to help, but you are also revolted and want to run and ignore its plight. However, you recognise that the right thing to do, the act of which others would approve, is to help and end the cat's life: you want to want to end its life (and logically want to not want to ignore its plight). There are desires, second order ones (the desire to foster or

\footnotetext{
8 David Hume, An Enquiry Concerning the Principles of Morals (London: Hackett, 1983).

${ }_{9}^{9}$ Roger Scruton, Sexual Desire: A Pbilosophical Investigation (London: Continuum, 2006), 343.

${ }^{10}$ I ignore the controversial empirical claim that there is a causal relationship between consumption and violence to others. See Diane Russell, "Pornography and rape: a causal model," Political Psychology. 9.1 (1988): 41-73. I have discussed this elsewhere, see Rose, The Ethics and Politics of Pornography, 75-78.

${ }^{11}$ Georg Wilhelm Friedrich Hegel, Elements of the Philosophy of Right, trans. Barry Nisbet (Cambridge: Cambridge University Press, 2002).
} 
inculcate the first order desire), which ought to be cultivated because these are those of the moral agent. ${ }^{12}$ Such motivations are values. ${ }^{13}$

\$14. The agent should want to not be aroused by sexual violence. This is to make a moral judgement, not one of taste and the moral judgement is based on a controversial account of what is and what is not good behaviour, value or sexual behaviour. What are the pursuits or values of the good sexual being? Now, if someone takes pleasure from scenes which are vulgar or disgusting, we treat it as a matter of bad taste and the best that the "ought" can hope for, is that one should not take pleasure from such scenes if one wishes to be considered a good judge or have a good sense of humour or some such judgement (An explanation which is ultimately circular.). What seems at stake is the claim about desirable activities and a certain shadowy puritanism that dictates what are and what are not approved sexual practices and arousing images.

\section{Objectification: Pornography as Knowing}

$\$ 15$. Moral wrongdoing has, it seems, less to do with production of sexually violent films and more to do with consumption. Following this train of thought allows one to sidestep all the worries about the wrongness of sexually explicit graphic novels, literary erotica, simulated violence and simulated underage or animated underage participants since the wrongdoing is about seeing and consuming these images and words. (See $\mathbb{} 2$ above.) The discourse as a whole is guilty of objectification:

Pornography's knowledge is harm, because the creation of knowledge, through pornography, and the objectification of women by pornography are two sides of the very same phenomenon. On MacKinnon's way of thinking, pornography is a certain kind of self-fulfilling projection. That is what makes it a source of knowledge, and that is what makes it a kind of objectification. Part of the harm is in the shape that is projected: the vision of what women are like-servile, inferior, less-than-human. And part of the harm is also in the shaping, the fact that the projection becomes, in the contexts of oppression, a self-fulfilling one. ${ }^{14}$

$\$ 16$. Those consuming or producing pornography may well believe they want to and have a right to do so as an expression of their liberty. The mistake, though, is that one can treat others in humiliating and degrading ways only if they have consented and because the images involve an objectification of general types and not particular individuals, not all those affected by the representations have consented. For ease, let us concentrate on women as a type: representations of women in sexually violent material ("servile, inferior, less-than-human") objectify women such that it constructs a projection of women as "means merely." 15 The critic of pornography assumes he knows better what the actor wants because her participation in the film is to promote and maintain institutions and conventions which are actually against her interests through the objectification of certain

12 Charles Taylor, "What is human agency?" Human Agency and Language: Philosophical Papers 1 (Cambridge: Cambridge University Press, 1985) and Harry Frankfurt, "Freedom of the Will and the Concept of a Person," Journal of Philosophy, 67.1 (1971): 5--20. Please note some second order desires might just be trivial and only some are values.

13 Susan Wolf, Freedom within Reason (Oxford: Oxford University Press, 1993).

14 Rae Langton, Sexual Solipsism: Philosophical Essays on Pornography and Objectification (Oxford: Oxford University Press, 2009), 307.

15 Immanuel Kant, Groundwork of the Metaphysics of Morals, trans. Mary Gregor (Cambridge: Cambridge University Press, 2012), 433. 
images of women which then frustrate her own goals as well as those of other women. She wants to achieve value in her life through an institution which actively undermines the status of her gender in society and her own possibilities to satisfy herself through her projects. If she knew this, she would not participate but her participation illustrates that she does not know this, and the critic must make the decision on her behalf. To consume pornography is to perpetuate and consolidate the means of this oppression.

\$17. When my computer crashes and takes with it my article being written, I swear at the machine and blame it. This is a subjectification of the computer and it is a mistake. It is not an agent, it did not do the crashing. With objectification, the opposite error is committed: I categorize an agent as an object, as not having a will of its own and not being able to decide for itself. One's initial metaphysical error has consequences: not only do we understand the world wrongly, we also act on the basis of our understanding and do so in morally wrong ways. It is as wrong to hit a PC with a cane as it is to assume women, as a group, enjoy sexual humiliation and degradation.

\$18. Nussbaum and Langton list ten ways one can treat a subject as an object. ${ }^{16} \mathrm{I}$ treat a subject as an object when I see him or her as:

1. a tool to further my own interests (instrumentality);

2. lacking autonomy and self-determination (denial of autonomy);

3. lacking agency and/or activity (inertness);

4. interchangeable with other objects of the same or other types (fungibility);

5. something that it is permissible to break up, smash or break into, lacking in boundary integrity (violability);

6. as something that can be owned, exchanged (ownership);

7. whose feelings and experience need not be considered (denial of subjectivity);

8. reduced to his or her body or parts of the body;

9. reduced to his or her appearance;

10. being silenced.

However, it is obvious that 1, 5,8 and 9 can all be permissible when conditions of consent are met. 6 also in part, again determined by consent and its necessary exit clause (which differentiates slavery from labour). ${ }^{17} 2,3,4,7$ and 10 all rest on the status of the agent as agent or the recognition of the agent as self-determining, capable of rational choice and in charge of himself or herself. In short, all the conditions of objectification stem from Kant's claim that treat one as an end never merely a means.

$\$ 19$. I can make my inner life appear to you in one way rather than another through the free choice of clothes, the purchase of a specific car or mobile phone, using a specific accent or diction, aligning myself with certain groups or telling you what I believe and hold most dear. These institutions (property, language, et cetera) are media through which my selfhood is expressed, through which you understand me as an agent. Objectificationpresenting my inner world in objective form-is a necessary part of human existence and it is achieved through institutions which pre-exist the agent and make possible that representation. To choose and partake in labour activities makes possible the expression of my individuality; if I choose to teach rather than build houses, to act rather than work in

16 Martha Nussbaum, “Objectification,” Philosophy and Public Affairs. 24.4 (1995): 249-291. Rae Langton, Sexual Solipsism, Chapter10.

${ }^{17}$ David Edward Rose, The Ethics and Politics of Pornography, Chapter 5. 
investment banking, and to perform in sexually violent pornographic films rather than appear in amateur theatre, I am expressing something I value. Reciprocally so with those objects and activities I choose to consume: my clothes tell you of my musical tastes, my car of what I believe is a worthwhile life and so on.

$\$ 20$. However, the system of meanings, expectations and institutions including language and cultural attitudes can distort and make impossible the proper communication of one's inner will. Imagine moving to a culture where raising one's hand was an expression of dissent (of not wanting to answer a question in class) rather than assent. The agent for the first few months in this new culture would be misunderstood and would have to learn to comply pretty quickly in order for him to express what he truly wants. The existence of pornographic material (whether written, filmed, photographed, drawn) determines the understanding of a particular group (women). Violent representation is particularly pernicious in that it reinforces the view that women want to be humiliated, are happy to be inferior, enjoy being subservient, as having their will ignored and contradicted (of meaning yes when they say no). The problem with the representation of sexual violence is that it is based on a suspension of disbelief and background lying that the person wants to be hurt, takes pleasure from being hurt.

$\$ 21$. Pornography produces knowledge. Propositions are normally understood to mirror reality and their truth value is a correlate of their capacity to best represent what is. In a very broad sense, then, reality causes the content of propositions. Objectification is a problem because it falsely represents reality: the content of the propositions claim that women are not agents or are not subjects. However, there are other propositions, normative in nature that cause reality to be what it is. So, in the mid-seventeenth century in Europe, a claim that had origins in Christianity began to surface: all humans are equal. It was clear that as a statement of fact, this was (and perhaps still is) false, but rather it was the declaration of a moral and political project which would play out over the next four hundred or so years. What the people who held this claim wanted was a world in which this was true and through political activity, rebellion and revolution, they made such a statement more or less true in the construction of institutions which would guarantee the equality of agents. They made the world become what they wanted it to be. The desire then became a truth. The internal sentiment that all humans are equal confers a value on an object (members of a lower class, women, slaves) which strives to be taken seriously as an objective feature of the object. Or, the desire for something to be thus and so generates the belief that something is thus and so (so the desire for equality actually makes us believe people are equal and solidifies this in institutions which support equal status).

$\$ 22$. Projected desires can also be negative. The most obvious case of such objectification occurs in gender and race relations. Every culture has the fall guy for its jokes: the Irish, the Polish, the English and so on. The majority of these jokes are not malicious, they ascribe the property of foolishness, stinginess or illiteracy to a general category. The problem is that at a job interview where one is interviewing a woman and a man, or an Englishman and an Irishman, for the same job, deep unconscious associations may impact one's decision making process. The cultural understanding of the individual as an object belonging to a set precedes and filters one's judgement of him or her. The desire of men for women creates the relationship between perpetrator and victim in that the woman is cast in the role of wanting or asking for it, even if she openly dissents, a stereotype all too prevalent in much unreflective pornographic material. The commodification of women's sexuality through pornography is a way to create the coding of desirable women, so that the desires of men 
are reproduced, and complicity accepted by women who wish to be desired (in order to further their own interests) just as the pupil in $\$ 20$ must learn the new rules of hand-raising. If the women want to have their own interests satisfied in our society, then they must conform to what society expects them to be.

\$23. However, I really want to believe in Santa Claus and become fixated on the idea that the impersonator at my local department store in December is, in fact, Santa Claus. My desire for there to be a Santa Claus generates the belief that he is Santa Claus and my willingness to dote on him confers on him the very values of Santa Claus: generosity, patience and kindness. Yet such a belief is untenable because he will take off his costume and he won't come to my house on Christmas Eve. Reality has a tendency to crush inappropriate beliefs. I can act in the world to make this true only at the expense of his freedom of will: by forcing him to be Santa Claus, to live eleven months of the year in Lapland and to descend down all chimneys on Christmas Eve.

$\$ 24$. Sexual objectification is not revealed to be inappropriate in the same way. An imagined nightclub prowler has a belief that women are agents with wills of their own and the consequence of such a belief frustrates his desire to take non-consensual delight in their mere appearance or in treating them as objects of consumption as they pass him by in the club. To further his interests, it would be better that they were mere objects, subject to his will and choice, without desires and an inner life of their own. To view them in this way requires epistemic bad faith: he must repress the knowledge that they are subjects and hope that this repression is not revealed to him at an inopportune moment. His consumption of sexually violent material allows him to perform his master-stroke of epistemic bad faith, to create the neurosis akin to that of the Santa Claus believer. What separates them is that the Santa Claus believer is vulnerable to the revelation that his belief is false because the world will not conform to his desires, whereas the male fabricated world of social reality maintains and supports the epistemic bad faith of the nightclub prowler. His belief is not vulnerable in the same way because it is shared and being shared with his peers: when the women tries to dissent, she is merely playing the game, pretending not to be what she is, as the films often portray.

$\$ 25$. A consequent is that one cannot find fault with, or the same fault with, gay sexual violence or female on male sexual violence. (See $\$ 35$ below.)

$\$ 26$. However, let us return to the subjectification of the computer and my smashing it with a baseball bat to punish it. I am well aware that my behaviour is absurd, that the computer cannot be blamed. My violent outburst is merely a way to diffuse frustration and anger. I know that the computer is a thing and that I am making a category mistake when I ascribe certain properties to it, so at worse I am guilty of an epistemic bad faith. However, from such bad faith, no moral normative consequences of worth follow as they would if I were to demand that the police arrest the computer. What is significant about this attitude, though, is the parallel of epistemic bad faith with objectifying judgements and its origin in human interest. Let us return to our nightclub crawler. What is true about his comportment toward the women is that he knows that they are subjects, but forgets, represses or denies such a status. His behaviour is reprehensible for this fact: there is an appropriate way of understanding what is before him, a demand made by the nature of the thing to be known, that he, because it suits his interests or just because he can, given the structures of his consciousness, revel in denying. And unlike the computer, moral consequences follow from his epistemic bad faith: whereas the computer can be understood wrongly, this is neither 
here nor there for the computer, but it is very significant for the women to be understood as they are. The women would object to his treating them as objects and they would, if asked, demand that he stops.

$\$ 27$. Fiction mediates our own expression by replying on a background of fact. Watching, reading or consuming it involves learning from it, but given the nature of fictional works the factual web that supports a work of fiction can generate mistakes in readers. First, a reader may mistake background for mere fiction (and does not learn what he should learn). Second, a reader may mistake mere fiction for background (and learn what he should not); for example, that time-travel is possible through wormholes. The latter would seem to be the case with pornography: the pornographic film asserts that "Women mean yes when they say no," or "Women need to be brought to an understanding of the own innermost desires." Just as deep cultural associations affect my deliberative choice between two applicants for the one job, unbeknownst to me due to my having learned a trait of a race which is not true and does not apply to the individuals before me, so too with pornography and women. Or, pornography may represent women as compliant, yet coquettish and such a characterization is necessary for the narrative to function (hence is background) in the same way time travel is a necessary background for certain science fiction films yet is fiction. As such, if the background structure is taken to be true, then pornographic films affect the possibility to enunciate and the effectiveness of an act of dissent. One can go further: the fact-fiction blurring is intentionally brought about by the agency of someone who has something to gain from such and such a mistake. Think of an actual woman in the images from Crepax's Valentina (fig. 1). What would her feelings be if it were a real, unchosen situation? She would be terrified, scared, in pain-we as viewer would want to free her unless she explicitly forbade us. The only way we are aroused if we think she secretly enjoys it, has consented. One's immediate encounters with others in a sexual situation are sometimes corrupted because one possesses background beliefs that may well be false and obstructs the proper expression of agreement or refusal.

$\$ 2$. Pornography's silencing of women rests on a claim about the construction of social reality: objectification creates, maintains and informs social and cultural conditions of understanding such that it is easier for knowing subjects (both male and female) to perform the epistemic bad faith required to objectify persons belonging to a specific set and such objectification has negative normative consequences in that it undermines the moral value of a subset of persons by reinforcing inequality (subordinating) and denying the autonomous and rational status of this subset (silencing).

\section{Objectification versus Alienation}

\$29. A proper understanding of objectification differentiates between objectification and alienation. Objectification in and of itself is not bad. Objectification occurs when the product of my activity is the objectification of my will in the world, the object is recognised as mine, as an expression of myself. Objectification is negative when it is alienation, when the product of my activity is taken away from me and posited as not-mine, or when it makes it impossible for me to express my will as I would wish in the world. A group is alienated in that they cannot find satisfaction in those structures which render them meaningful agents. Subjective freedom stipulates that a self-understanding be recognized as valid for the agent by himself because I am not "at home" when I act on external dictates imposed on me. The moral subject must endorse the good as his or her own good. Objective freedom is the institutional and social structure of the world which makes it possible for the person or 
subject to satisfy his or her subjective freedom. ${ }^{18}$ The objective freedom of an agent is the institutions, moral values, social fabric, roles, civil, economic and political structures and so on that guarantee his or her identification as a subject of his or her own deeds and his or her recognition as a moral agent (and not an animal, a very young child, a slave and so on). So, for example, capitalism, the family and the Christian tradition are all forms of objective freedom: they assign roles and duties that determine how we behave in certain situations and in behaving in accordance with their dictates (or, at times, violating them) we are able to be, and also understood as, an agent.

$\$ 30$. Representations of sexual violence, it could be argued, alienate because they frustrate and obstruct free self-understanding. Women understood by consumers of pornography and sexually violent imagery are silenced, because their protestation is ignored ("She says no, but she means..."), cries of pain and expressions of humiliation are interpreted as expressions of pleasure, implorations to stop are interpreted as encouragement to continue. Women cannot recognise themselves in the images portrayed and their agency is negated in actual relationships because what they say is never understood to be what they mean. They cannot be "at home" in the cultural discourse which maintains and supports their expression. They are alienated from their cultural understanding. One might say, violent pornography is wrong because it is a representation and hence a reinforcement of gender hierarchical power relationships; predominantly man or men on women. This means we can make the same judgement about graphic novels as well as films, and also mainstream cinema, such as Hostel II. Furthermore, there is no difference between a simulated and a real scene.

$\$$ 31. Inequality arises from the creation of ideology which supports interest-driven attitudes and ideology is insulated from critique by the silencing of dissent through social and cultural institutions (including pornography) which reinforce the "truth" of these attitudes. Such institutions, discourses and social practices subordinate the wills of those silenced by the power structures through producing individual wants, needs and interests consistent with the original desires of the creators. The oppression is so great that women begin to falsely recognise themselves in the representations of the discourse of pornography; their wants are not considered worthy of equal respect, or they are obstructed from articulating their own wants because language and the discourse of sex make it possible for them to express their wants only at the cost of their own rationality. Pornography depicts a world which rests on a particular view of what a sexual woman is in order to satisfy the interests of the nonwoman. And women, then, are alienated from their own determination and products of their wills.

$\$ 32$. To say, though, that a decision has been taken by a will other than the woman's, that is by the Male's wish to subordinate women in such a way, and to conceive of such an act as a momentary, ahistorical and precise act of will is to rely on a rather mythical, metaphysically problematic conception of the Male. Langton establishes the critique of pornography on its role in projection with a rather rhetorical thought experiment. ${ }^{19}$ She imagines a conspiracy designed and implemented by, one assumes, an evil, male genius whereby the origins of the need to see women as objects is separated from that need and given the convincing veneer of naturalistic science. Moreover, the limits and rules of what constitutes science is set by the same male genius who also dictates what is to count as evidence that confirms or falsifies a belief. Over a period of time, the cultural and social institutions of the world

\footnotetext{
18 Georg Wilhelm Friedrich Hegel, Philosophy of Right, \$132.
}

19 Rae Langton, Sexual Solipsism, 261-266. 
created by this genius will begin to actually confirm these propositions as truth: if a certain race is kept in slavery for a period of generations and excluded from education, then such a race will in fact exhibit the properties of servility and dependence. The problem with her picture is twofold. One, her account of objectification depends upon an original act of will, a decision by one or a group of males to instigate a system of domination through language and cultural institutions; the "ur-Father" of feminism. And it also depends on placing the blame on those individuals who benefit from but did not create this system. Yet, if the silenced cannot overthrow the system, the voiced do not actively reinforce it. They are as much victims as the women since their role in the system is equally determined. Who is it that actually lies and creates the fiction which then becomes "reality"? It is not a particular male or even an historical one. Looking for blame in a modern sense of trying to identify the agent (the actor in the film, the consumer or the producer of the film) may well be the greatest distortion of all. Two, such an account undermines what it seeks to defend: the autonomy of women. It paints a picture of a "woman" who exists silently and outside of the system of power and unable to influence it. Surely feminism requires a better heroine.

$\$ 33$. Moreover, if the existence of pornography creates, maintains and informs social and cultural conditions of understanding such that it is easier for knowing subjects (both male and female) to perform the epistemic bad faith required to objectify persons, why is the critique of pornography explicitly feminist? There are male actors in the films as well and they, too, behave in ways that may make women form false beliefs: men are only interested in sex, men comply with the desire to make love without reservation, plumbers are horny, and the average size of the male member is about twelve inches long. Such background may create a situation in which a woman (or another man) may form beliefs about the individual man in front of them because the woman wants it to be thus and so. Neither "male" nor "female" feel at home, let alone the bisexual, the homosexual, the asexual and so on. What the feminist will say is that such beliefs are not supported by the society at large, though. They will be more akin to the belief that the man in the store is actually Santa Claus (see $\int 23$ above): if I were to share such beliefs, others would dismiss them, whereas the beliefs about women are more likely to be supported by others because the cultural conditions of inequality support them. Male beliefs, in short, can move from unstable objectification to cultural alienation. The second thing the feminist may say is that whereas the background lies, and the epistemic bad faith of the male is in his interest, the background beliefs of the woman about men (based on pornography films) are also in his (and not her) interest.

$\$ 34$. There is a difference between the institutions that exist to maintain and support the social reality of equality between individuals and those that exist to maintain and support the presentation of groups as inferior, servile and not fully rational in the interests of the constructors of social reality. In Hegel and also in Marx, the opposite of alienation is freedom and homeliness or interdependent freedom, an act is an expression of will when the agent who creates (i) sees what he produces and consumes as worthwhile and valuable to him and others; and (ii) knows that it is his free choice to produce and consume it (that is participate in the decision-making process which decides which goods are to be produced). ${ }^{20}$ Alienation occurs when systems of domination and control determine the expressions and consumption of desires without the participation of those agents. The existence of pornography creates, maintains and informs social and cultural conditions of

${ }^{20}$ Georg Wilhelm Friedrich Hegel, Pbilosophy of Right. Karl Marx, The German Ideology, trans. S. Ryazanskaya (New York: Prometheus Books, 1988). 
understanding such that it is easier for knowing subjects (both male and female) to perform the epistemic bad faith required to objectify persons belonging to a specific set; and such objectification has negative normative consequences in that it undermines the moral value of a subset of persons by reinforcing inequality (subordinating) and denying the autonomous and rational status of this subset (silencing). That pornography aids in the objectification of persons is neither here nor there. It, in this respect, performs the role of many other institutions, conventions and meanings in that it sets down the manner in which we can understand others and their behaviour and also express ourselves. To describe such action as epistemic bad faith is rhetoric, because it could easily be understood as a way to subjectify myself and others: through these understandings I allow my individuality to be stated and respected. The trouble is not an original act of will on the parts of a group of males or the consolidation of inequality by an actual group of males, but that the interests at stake are commodity production and profit. One cannot feel at home in the representation of sexual activity because it represents behaviours and expectations which meet the accumulation of capital and not free choices of human beings.

\section{Pornography and Capitalism}

$\$ 35$. The representation of our sexuality which exist is for the most part determined by capital. There is no original act of will which generates a hierarchy of power just the system of production and consumption which alienates us both from the producing and consuming activity. Nowhere does the female, male, homosexual, heterosexual or individual himself, herself or zirself choose the means and discourse of expression which is wholly dominated by the distorting need to accrue capital. For the most part, the production and creation of sexual discourse and tropes is produced by those with an interest in commodifying it and not those who seek to freely express themselves in it.

\$36. A proper critique of sexually violent imagery should then be aimed at the cultural conditions of understanding (capitalism) and not some imagined individual who seeks to oppress a group. By assuming that one can trace the wrongdoing to a decision on the part of a fixed subjectivity, one undermines any real understanding of sexual representation. Pornography is a capitalistic simulation of alienation. The sexual other is understood as an instrument for my pleasure and the individual's sexuality is seen as a commodity to be exchanged in the marketplace. The subject cannot feel at home in the modes of behaviour that constitute his or her sexuality (we do it despite ourselves) and we are in competition with others because our body can be replaced by any other object. Our sexuality and its representation, through which we find meaning (pornography), is distorted by capitalism. The existence of images of violent pornography (whether simulated or real), like the existence of pornography representing children (whether real or not), is wrong because it distorts the relationships between individuals and makes proper free agreement and consent between individuals impossible and corrupt. The atomism of modern society and the representations of sexual relationships in the media frustrate rather than develop sexual relationships. Expressions of sexual activity can only meet free conditions when they are socially self-determined activities and not one of commodity value production. The violent nature of these images is a red herring.

\$37. So, should violent sexual imagery like pornography in general be prohibited because it is alienating? The opposite of alienation is free activity when the agent can find satisfaction in those activities maintained and supported by the institutions and expectations of culture. One cannot ban or prohibit the whole of culture and such a goal is undesirable anyway: one 
annihilates the very means of one's own free expression. The discourse of pornography, with all its variety and flavours and the social reality it constructs, is necessary for individuals to find satisfaction in their relationships: otherwise we would have to always start from zero and rebuild everything, the expectations, tropes of behaviour and possible models of satisfaction. The variety of pornography, including the expression of tastes in sexual violence, so long as they are regulated by state control, allows us to find objectifications in which we can feel at home. Prohibition undermines state regulation and protection of participants and removes the means for self-expression. The requirement is that we, as individuals, participate in the construction of that sexual reality through engaging with the productive process and not ignoring or pushing it into the shadows.

\section{References}

Philosophical Texts

Carroll, Noel. The Philosophy of Horror, Or, Paradoxes of the Heart. New York: Routledge, 1990. "Enjoying Horror Fictions: A Reply to Gaut." The British Journal of Aesthetics. 35.1 (1995): 67-72.

Dines, Gail. Pornland: How Porn Has Hijacked Our Sexuality. Boston: Beacon Press, 2014.

Dworkin, Ronald. "Is There A Right To Pornography?" Oxford Journal of Legal Studies. 1.2 (1981): 177-212.

Frankfurt, Harry. "Freedom of the Will and the Concept of a Person." Journal of Philosophy. 67.1 (1971): 5-- 20.

Gaut, Berys. "The Paradox Of Horror." The British Journal of Aesthetics. 33.4 (1993): 333-45. . "The Enjoyment Theory of Horror: A Response to Carroll." The British Journal of Aesthetics. 35.3 (1995): 284-89.

Hegel, Georg Wilhelm Friedrich. Elements of the Philosophy of Right. Translated by Barry Nisbet. Cambridge: Cambridge University Press, 2002.

Hume, David. An Enquiry Concerning the Principles of Morals. London: Hackett, 1983.

Kant, Immanuel. Groundwork of the Metaphysics of Morals. Translated by Mary Gregor. Cambridge: Cambridge University Press, 2012.

Langton, Rae. Sexual Solipsism: Philosophical Essays on Pornography and Objectification. Oxford: Oxford University Press, 2009.

Mackinnon, Catherine. Only Words. Cambridge, USA: Harvard University Press, 1993.

Marx, Karl. The German Ideology. Translated by S. Ryazanskaya. New York: Prometheus Books, 1988.

Nussbaum, Martha. “Objectification.” Philosophy and Public Affairs.24.4 (1995): 249-291.

Rose, David. The Ethics and Politics of Pornography. Basingstoke: Palgrave Macmillan, 2013.

Russell, Diana. "Pornography and rape: a causal model." Political Psychology. 9.1 (1988):41-73.

Scruton, Roger. Sexual Desire: A Philosophical Investigation. London: Continuum, 2006.

Strohl, Matthew. "Horror and Hedonic Ambivalence." The Journal of Aesthetics and Art Criticism. 70.2 (2012): 203-12.

Taylor, Charles. "What is human agency?" Human Agency and Language: Philosophical Papers 1. Cambridge: Cambridge University Press, 1985.

Wolf, Susan. Freedom within Reason. Oxford: Oxford University Press, 1993.

\section{Literary Texts}

Crepax, Guido. Valentina. Vol. 5. Roma: Blue Press, 1995.

Milton, John. Paradise Lost. London: Penguin, 1968. 
Wolfman, Marv. "Hell is the Hangman!" Spiderwoman. 1.4. New York: Marvel Publications, 1978.

\section{Filmography}

Hodges, Mike, dir. Flash Gordon. Starling Films (1980): 111 mins.

Roth, Eli, dir. Hostel: Part 2. Lionsgate (2007): 94 mins.

Travis, Graham, dir. Wasteland. Elegant Angel (2012): 134 mins. 